\title{
Influence of dietary mineral sources on milk yield and composition of West African Dwarf Does
}

\author{
Olaniyi T. A. ${ }^{*}$, Aina A. B. J. ${ }^{2}$, Sowande O. S. ${ }^{2}$ and Williams T. J. ${ }^{2}$ \\ ${ }^{1}$ Federal College of Animal Health and Production Technology, Moor Plantation, Ibadan, Nigeria. \\ ${ }^{2}$ Federal University of Agriculture Abeokuta, Ogun state, Nigeria. \\ *Corresponding author. Email: olaniyitaiwo537@gmail.com
}

Copyright (C) 2018 Olaniyi et al. This article remains permanently open access under the terms of the Creative Commons Attribution License 4.0, which permits unrestricted use, distribution, and reproduction in any medium, provided the original work is properly cited.

Received 6th December, 2017; Accepted 12th January, 2018

\begin{abstract}
This study investigated the effects of different mineral nutrient sources (local potash ("kaun"), mineral lick and ruminant mineral premix) on milk yield and composition of West African Dwarf does. Twelve WAD goats (first parity does), weighing between $13.00 \pm 3.79$ and $14.33 \pm 4.83 \mathrm{~kg}$, were divided into four groups with three does per treatment; $0 \%$ mineral (OMC), $2 \%$ local potash (2LP), mineral lick (2ML) and mineral ruminant premix (2RMP). The experiment lasted for 180 days (150 days pregnancy, 30 days milk collection). Data collected on the milk yield and milk composition of WAD does were analysed using One-way analysis of variance (ANOVA), significant means were separated using Duncan Multiple Range Test. Result revealed that for total milk yield and daily milk yield, does in 2ML (5919.67 milliitre/animal, 197.32 millilitre/animal/day), 2LP (5852.00 millilitre/animal, 195.07 millilitre/animal/day) and 2RMP (5131.00 millilitre/animal, 171.03 millilitre/animal/day) had the highest $(p<0.05)$ values with $0 \mathrm{MC}(1642.67 \mathrm{milli}$ itre/animal, 54.76 millilitre/animal/day) having the least values. For colostrum lactose, 2RMP $(4.33 \pm 0.15 \%)$ and 2 PLP $(4.10 \pm 0.21 \%)$ had the highest $(\mathrm{p}<0.05)$ values followed by $0 \mathrm{MC}(3.97 \pm 0.27 \%)$ and $2 \mathrm{ML}(3.30 \pm 0.25 \%)$. While, in milk total solid, $0 \mathrm{MC}$ $(11.40 \pm 0.35 \%)$ had the highest $(p<0.05)$ value followed by $2 \mathrm{ML}(10.43 \pm 1.03 \%)$ and $2 \mathrm{RMP}(9.87 \pm 0.32 \%)$ with $2 \mathrm{LP}$ $(8.93 \pm 0.43 \%)$ having the least values. The study concluded that for high milk yield, diets containing $2 \mathrm{ML}$ could be fed to does.
\end{abstract}

Key words: Parity, minerals, milk yield, milk compositions.

Abbreviations: 0MC, 0\% mineral; 2LP, 2\% Local Potash; 2ML, 2\% mineral lick; 2RMP, 2\% Ruminant Mineral Pre-mix; WAD, West African Dwarf does.

\section{INTRODUCTION}

Goat is among the earliest small ruminant species to be domesticated and has been used as source of meat and milk since 2500 B.C. (Dubeuf and Boyazoglu, 2009). Blench (1999) published the characterisation of the traditional varieties of goat in Nigeria. Three main varieties of goat are recognised in Nigeria, the Sahel, the Sokoto Red and the West African Dwarf. Goats are renowned for their hardiness and can survive in most environments. It is a small fine goat famous for its skin used for wool and then as hide (Aina, 2012). The intestine of goat is used to make "Catgut", which is still in use as a material for internal human sutures. The horn of the goat, which signifies well- being is also used to make spoons (Aina, 2012). The colour varies from white to black background or white spots on a black background. They are scavengers and trypano-tolerant. They have height at wither of up to $65 \mathrm{~cm}$ with an average mature weight of 20 to $25 \mathrm{Kg}$. Goats in Nigeria are kept mainly for meat production but milk is not substantially consumed (Midau et al., 2010). Milk is an excellent source of most essential minerals for humans such as calcium, phosphorus but low in copper, iron and manganese (Belewu and Aiyegbusi, 2002).

Minerals contribute to the buffering capacity of milk, eminence of milk $\mathrm{pH}$, ionic strength of milk and milks 
osmotic pressure (Hurley, 2002). A study carried out to compare the mineral composition of human, Fulani cow and West African Dwarf goat milks concluded that the milk of goats contained more of minerals and that the minerals present were similar to those present in human milk (Belewu and Aiyegbusi 2002). Dietary characteristics influence milk yield and milk composition of dairy goats, as well as body weight gain (Min et al., 2005). Mineral deficiency may be linked to problems such as occasional staggering gait, uncoordination of movement and depigmentation of hair in goats (Aina and Akinsoyinu,1996), retained foetal membranes (Gupta et al., 2005), abortion (Mee, 2004) and weak calf syndrome (Logan et al., 1990). The beneficial responses of cattle and sheep to mineral supplementation have been investigated (Ogebe et al., 1995). Thus there is the need to contribute to existing knowledge on mineral nutrients as a determinant in goat milk yield and characteristics. Hence, this study investigates the Influence of dietary mineral sources on milk yield and composition of WAD Does.

\section{MATERIALS AND METHODS}

\section{Location of the experiment}

The experiment was carried out in the Small Ruminant Unit of OLAD's Farm Camp in Odeda Local Government Area of Ogun State, Abeokuta. The site is located in the rain forest vegetation zone of Southern - Western Nigeria on Latitude $7^{\circ} 10^{\prime} 50^{\prime \prime} \mathrm{N}$, longitude $3^{\circ} 26^{\prime} 37^{\prime \prime} \mathrm{E}$ and altitude of $169 \mathrm{~m}$ above the sea level.

\section{Animals and their management}

Twelve first parity WAD does, weighing between $13.00 \pm 3.79$ and $14.33 \pm 4.83 \mathrm{~kg}$, were quarantined for a period of four weeks prior to the commencement of the study. During this period, oxytetracycline and a multivitamin preparation were administered at the rate of 1 $\mathrm{ml}$ per $10 \mathrm{~kg}$ body weight through intramuscular route for prophylactic treatment. The animals were group fed on mixture of cassava peels $(40 \%)$, palm kernel cake $(20 \%)$ and wheat bran (40\%). Feed and Water were supplied adlibitum.

\section{Experimental diets preparation}

Local potash ("Kaun"), mineral lick and ruminant mineral premix were used in this experiment. Four isonitrogenous and isocaloric concentrate supplement of $0 \%$ mineral (OMC); $2 \%$ Local Potash (2LP); $2 \%$ mineral lick (2ML) and $2 \%$ Ruminant Mineral Premix (2RMP) were formulated as illustrated in Table 1.

\section{Experimental design}

Twelve (12) goats were divided into four groups. Each group of three goats was randomly allocated to any of the four treatments $0 \%$ mineral, $2 \%$ local potash, $2 \%$ mineral lick, and $2 \%$ mineral ruminant premix. The animals were individually housed in a slated floor pen of three replicates in a group as indicated below:

$0 \%$ Mineral (control) (OMC)

$2 \%$ Local Potash (2LP)

$2 \%$ Mineral Lick (2ML)

2\% Ruminant Mineral Premix (2RMP)

\section{Synchronization of experimental animals}

The twelve WAD does were weighed and brought to heat (oestrus) through synchronization (Adebambo et al., 1994). Bucks of proven stock were allowed to serve the does. Pregnancy was affirmed after 30 days non-return to heat (150 days pregnancy, 30 days milk collection).

\section{Doe performance}

The daily weight gain of does was calculated by dividing the difference between the initial and final live weight by total number of experimental days (150 days of pregnancy).

\section{Milk collection}

Colostrum was collected day-one after parturition at $7 \mathrm{hr}$ and later taken for analysis. Mature Milk collection commenced on day 7 after parturition. Lactation length for each doe was based on 30 days (Williams et al., 2012). Prior to a milking day, kids were separated from their dams at $19 \mathrm{hr}$ preceding the day of milking, milk samples were collected twice daily at $7 \mathrm{hr}$ and $19 \mathrm{hr}$. Dams were allowed to nurse their kids in the morning after milking before separation.

The two halves of the udder were hand milked for about 5 to 7 minutes by expressing the milk from the udder of the animal into a clean bowl. The quantity of milk harvested from each doe was measured using graduated plastic cylinder (500 mL capacity) and weighed on a sensitive scale.

\section{Milk composition}

The total solid not-fat of milk were determined simply by evaporating the water and weighting the residue using forced draft oven method (Marshall, 1993). Butter fat 
Table 1. Composition of experimental diets (\%).

\begin{tabular}{lcccc}
\hline Ingredients & OMC & 2LP & 2ML & 2RMP \\
\hline Dried Cassava peals & 40 & 38 & 38 & 38 \\
Palm kernel cake & 20 & 20 & 20 & 20 \\
Wheat bran & 40 & 40 & 40 & 40 \\
Local potash & - & 2.0 & - & - \\
Mineral lick & - & - & 2.0 & - \\
"Ruminant mineral premix & - & - & - & 2.0 \\
Total & 100 & 100 & 100 & 100 \\
Calculated Nutrient composition (\%) & & & & \\
Crude Protein & 13 & 13 & 13 & 13 \\
Phosphorus & 0.02 & 0.02 & 0.02 & 0.02 \\
Calcium & 0.02 & 0.02 & 0.02 & 0.05 \\
${ }^{* *}$ Metabolizable Energy (Kcal/Kg) & 2802.8 & 2802.8 & 2802.8 & 2802.8 \\
\hline
\end{tabular}

${ }^{*}(40 \%$ egg shell $+40 \%$ table salt $+20 \%$ bone meal $) .{ }^{* *} \mathrm{ME}(\mathrm{Kcal} / \mathrm{kg})=37 \times \% \mathrm{CP}+81 \times \%$ EE $+35 \times \%$ NFE (Pauzenga, 1985).

content was determined using Gerber method following the procedure of Marshall (1993); Milk protein was determined using kjeldahl method; Ash was determined by graviometeric Method (Marshall, 1993). The lactose content was obtained by subtracting $\%$ fat, $\%$ protein and $\%$ ash from the total solid.

\section{Statistical analysis}

One way analysis of variance (ANOVA) in a completely randomized design was used to analyse the data (SAS, 2000). Means were compared using the Duncan's multiple range test of the same package. Mean differences were considered significant at $\mathrm{P}<0.05$. The statistical model was:

$\gamma_{i j}=\mu+\alpha_{i}+\varepsilon_{i j}$

Where: $\gamma_{i j}=$ individual observation, $\mu=$ general mean of population, $\alpha_{i}=$ treatment effect due to diets and $\varepsilon_{i j}=$ error effect.

\section{RESULTS}

\section{Analysed nutrient composition (\%) of experimental diets}

Table 2 shows the nutrient composition of experimental diets (\%).

\section{Performance and milk yield of goats (does) fed diets of different mineral sources}

Table 3 shows the performance and milk yield of goats (does) fed diets containing mineral from different sources. Treatment effects on performance was not $(P>0.05)$ significant except milk yield $(\mathrm{P}<0.05)$. For total milk yield and daily milk yield, does on 2ML, 2LP and 2RMP recorded the highest $(P<0.05)$ values $(5919.67,197.32$; $5852.00,195.07$ and $5131.00,171.03$ ) as animals on OMC $(1642.67,54.76)$ had the least values, respectively.

\section{Composition of colostrums of WAD goats fed diets containing minerals from different sources}

Table 4 shows the chemical composition of colostrum obtained from WAD goats fed diets containing minerals from different sources. Significant $(P<0.05)$ difference was observed in lactose and ash. Lactose in milk of does on diets 2RMP $(4.33 \pm 0.15)$ and 2LP $(4.10 \pm 0.21)$ are statistically similar and had the highest value than the other treatment diets $0 \mathrm{MC}(3.97 \pm 0.27)$ and $2 \mathrm{ML}(3.30 \pm 0.25)$, respectively. Does on diet 2LP $(0.74 \pm 0.04)$ had the highest value for ash followed by goats on OMC $(0.71 \pm 0.02)$ and $2 \mathrm{ML}(0.66 \pm 0.04)$ while animals on $2 \mathrm{RMP}(0.61 \pm 0.02)$ having the least value for ash in colostrum.

\section{Composition of mature milk of WAD goats fed diets containing minerals from different sources}

Table 5 shows the chemical composition of milk from WAD goats fed diets containing minerals from different sources. There was no $(P>0.05)$ significant effect of diets on all the parameters observed except in milk iron and total solid. In total solid, OMC $(11.40 \pm 0.35)$ recorded the highest value followed by $2 \mathrm{ML}(10.43 \pm 1.03)$ and $2 \mathrm{RMP}(9.87 \pm 0.32)$ with 2LP $(8.93 \pm 0.43)$ having the least values, respectively. 
Table 2. Analysed Nutrient composition (\%) of experimental diets.

\begin{tabular}{lcccc}
\hline \multirow{2}{*}{ Composition (\%) } & \multicolumn{4}{c}{ Treatments } \\
\cline { 2 - 5 } & $\mathbf{0 M C}$ & $\mathbf{2 L P}$ & $\mathbf{2 M L}$ & $\mathbf{2 R M P}$ \\
\hline Dry matter & 84.83 & 83.89 & 82.08 & 81.62 \\
Crude protein & 12.39 & 8.26 & 7.67 & 7.02 \\
Ash & 8.23 & 8.59 & 10.01 & 9.21 \\
Ether extract & 9.22 & 9.55 & 12.12 & 10.04 \\
Acid detergent lignin & 43.56 & 43.02 & 41.96 & 46.12 \\
Neutral detergent fibre & 80.43 & 65.28 & 87.31 & 96.34 \\
Acid detergent fibre & 35.27 & 30.61 & 31.62 & 35.52 \\
Cellulose & 10.17 & 11.43 & 12.86 & 14.11 \\
Hemicellulose & 17.21 & 2.06 & 7.44 & 9.80 \\
Calcium & 0.21 & 0.28 & 0.36 & 0.36 \\
Phosphorus & 0.15 & 0.18 & 0.17 & 0.29 \\
Magnesium & 0.2 & 0.27 & 0.32 & 0.3 \\
Chlorine & 0.08 & 0.06 & 0.14 & 0.12 \\
${ }^{*}$ Metabolizeable Energy $(\mathrm{Kcal} / \mathrm{kg})$ & $2,817.82$ & 2727.53 & 2683.81 & 2644.26 \\
\hline
\end{tabular}

${ }^{*} \mathrm{ME}(\mathrm{Kcal} / \mathrm{kg})=37 \times \% \mathrm{CP}+81 \times \%$ EE + $35 \times \%$ NFE (Pauzenga, 1985). 0MC, 0\% Mineral (control); 2LP, 2\% Local Potash; 2ML, 2\% Mineral Lick; 2RMP, $2 \%$ Ruminant Mineral Premix.

Table 3. Performance and milk yield of goats (does) fed diets containing mineral from different sources.

\begin{tabular}{lcccc}
\hline Parameters & OMC & 2LP & 2ML & 2RMP \\
\hline Initial DMI(g/ani/d) & $78.40 \pm 16.17$ & $88.33 \pm 22.46$ & $82.22 \pm 25.01$ & $91.68 \pm 21.55$ \\
Final DMI(g/ani/d) & $98.50 \pm 3.32$ & $644.95 \pm 526.49$ & $124.31 \pm 27.09$ & $136.14 \pm 37.65$ \\
Total DMI(kg) & $14.05 \pm 0.98$ & $21.22 \pm 6.59$ & $16.49 \pm 4.07$ & $18.54 \pm 4.23$ \\
Daily DMI(g/d) & $0.09 \pm 0.01$ & $0.14 \pm 0.04$ & $0.11 \pm 0.03$ & $0.12 \pm 0.03$ \\
Initial body wt(kg/ani) & $13.23 \pm 2.39$ & $14.33 \pm 4.83$ & $13.00 \pm 3.79$ & $13.33 \pm 3.33$ \\
Final body wt(kg/ani) & $19.17 \pm 3.63$ & $20.67 \pm 3.28$ & $20.17 \pm 4.00$ & $20.00 \pm 3.50$ \\
Total wt gain(kg/ani) & $5.93 \pm 1.46$ & $6.33 \pm 1.88$ & $7.17 \pm 0.44$ & $6.67 \pm 0.17$ \\
Daily wt gain(g/ani/d) & $0.04 \pm 9.75$ & $0.04 \pm 0.01$ & $0.05 \pm 0.00$ & $0.04 \pm 0.00$ \\
Total milk yield(ml/ani) & $1642.67 \pm 1186.88^{b}$ & $5852.00 \pm 1610.22^{\mathrm{a}}$ & $5919.67 \pm 345.88^{\mathrm{a}}$ & $5131.00 \pm 351.68^{\mathrm{a}}$ \\
Daily milk yield(ml/ani/d) & $54.76 \pm 39.56^{\mathrm{b}}$ & $195.07 \pm 53.67^{\mathrm{a}}$ & $197.32 \pm 11.53^{\mathrm{a}}$ & $171.03 \pm 11.72^{\mathrm{a}}$ \\
\hline ab: Means on the same row by factor with different superscripts differ significantly $(\mathrm{P}<0.05) ;$ wt, weight; DMI, Dry Matter Intake, \\
OMC, 0\% Mineral (control); 2LP, 2\% Local Potash; 2ML, 2\% Mineral Lick; 2RMP, 2\% Ruminant Mineral Premix.
\end{tabular}

While, in iron, 2RMP $(0.05 \pm 0.01)$ inducing the highest value followed by $2 \mathrm{ML}(0.03 \pm 0.01)$ while $0 \mathrm{MC}(0.02 \pm 0.00)$ and 2LP $(0.02 \pm 0.00)$ had similar and least value statistically and respectively.

\section{DISCUSSION}

Asaolu, et al. (2012) observed that feeds containing less than $8 \%$ crude protein $(\mathrm{CP})$ could not provide the ammonia levels required by rumen microbes for optimum activity. Yousuf et al. (2007) however opined that relatively high Acid Detergent Fibre (ADF) but low ether extract and crude protein contents were suggestive of low nutritional quality.
The dietary CP content as observed in this study ranged from 7 to 12 is within the level for optimum rumen microbial activities based on earlier report by Asaolu et al. (2012). The CP in this study is also within the values of 10 and $14 \%$ as reported by Abdu et al., (2012) and Okafor et al. (2012) respectively, for optimum sheep and goat production. Similar observations had been reported by Fasae et al. (2005) and Arigbede (2007). The results obtained might be an indication of the relatively good quality of the feeds. Ranjahan (2004) noted that a growing animal with insufficient dietary protein will reduce the efficiency with which it utilized metabolizable energy. The high ash content in 2ML and 2RMP could be taken as an indication of adequate mineral presence and availability. 
Table 4. Composition of colostrum from WAD goats fed diets containing minerals from different sources.

\begin{tabular}{lcccc}
\hline Parameters & OMC & 2LP & 2ML & 2RMP \\
\hline $\mathrm{pH}$ & $8.24 \pm 0.12$ & $7.31 \pm 0.27$ & $7.79 \pm 0.34$ & $7.86 \pm 0.39$ \\
& & & & \\
Gross composition (\%) & & & & \\
Total solid & $17.33 \pm 0.77$ & $18.19 \pm 1.32$ & $17.03 \pm 0.38$ & $17.90 \pm 1.21$ \\
Lactose & $3.97 \pm 0.27^{\mathrm{ab}}$ & $4.10 \pm 0.21^{\mathrm{a}}$ & $3.30 \pm 0.25^{\mathrm{b}}$ & $4.33 \pm 0.15^{\mathrm{a}}$ \\
Butter fat & $5.07 \pm 0.24$ & $4.53 \pm 0.34$ & $4.97 \pm 0.43$ & $4.57 \pm 0.34$ \\
Protein & $7.40 \pm 0.35$ & $7.03 \pm 0.09$ & $6.87 \pm 0.23$ & $6.77 \pm 0.18$ \\
Solid not-fat & $8.57 \pm 0.09$ & $9.43 \pm 0.38$ & $8.93 \pm 0.52$ & $9.27 \pm 0.07$ \\
Ash & $0.71 \pm 0.02^{\mathrm{ab}}$ & $0.74 \pm 0.04^{\mathrm{a}}$ & $0.66 \pm 0.04^{\mathrm{ab}}$ & $0.61 \pm 0.02^{\mathrm{b}}$ \\
& & & & \\
Mineral composition & & & & \\
Calcium & $118.33 \pm 5.49$ & $114.67 \pm 3.53$ & $123.67 \pm 2.03$ & $113.67 \pm 6.01$ \\
Magnesium & $12.93 \pm 0.58$ & $12.73 \pm 1.03$ & $12.50 \pm 1.13$ & $12.30 \pm 0.76$ \\
Phosphorus & $84.67 \pm 8.11$ & $81.67 \pm 1.45$ & $76.33 \pm 5.04$ & $82.67 \pm 6.89$ \\
Iron & $0.24 \pm 0.02$ & $0.23 \pm 0.02$ & $0.23 \pm 0.05$ & $0.32 \pm 0.04$ \\
Copper & $0.17 \pm 0.03$ & $0.14 \pm 0.01$ & $0.14 \pm 0.03$ & $0.16 \pm 0.04$ \\
Zinc & $2.81 \pm 0.21$ & $3.11 \pm 0.39$ & $2.37 \pm 0.13$ & $2.98 \pm 0.29$ \\
\hline
\end{tabular}

ab: Means on the same row with any different superscript are significant $(\mathrm{P}<0.05)$. 0MC, $0 \%$ Mineral (control); 2LP, $2 \%$ Local Potash; 2ML, 2\% Mineral Lick; 2RMP, 2\% Ruminant Mineral Premix.

Table 5. Composition of minerals of mature milk from WAD goats fed diets containing different sources.

\begin{tabular}{lcccc}
\hline Parameter & OMC & 2LP & 2ML & 2RMP \\
\hline $\mathrm{pH}$ & $6.60 \pm 0.21$ & $6.47 \pm 0.04$ & $6.40 \pm 0.03$ & $6.70 \pm 0.26$ \\
Gross composition (\%) & & & & \\
Total solid & $11.40 \pm 0.35^{\mathrm{a}}$ & $8.93 \pm 0.43^{\mathrm{b}}$ & $10.43 \pm 1.03^{\mathrm{ab}}$ & $9.87 \pm 0.32^{\mathrm{ab}}$ \\
Lactose & $3.17 \pm 0.33$ & $3.37 \pm 0.38$ & $3.37 \pm 0.37$ & $3.53 \pm 0.24$ \\
Butter fat & $3.33 \pm 0.44$ & $3.17 \pm 0.14$ & $3.10 \pm 0.25$ & $3.37 \pm 0.47$ \\
Protein & $4.00 \pm 0.20$ & $3.93 \pm 0.24$ & $3.83 \pm 0.15$ & $3.83 \pm 0.17$ \\
Solid non-fat & $7.87 \pm 0.64$ & $7.33 \pm 0.38$ & $7.27 \pm 0.69$ & $7.20 \pm 0.15$ \\
Ash & $0.61 \pm 0.04$ & $0.62 \pm 0.04$ & $0.64 \pm 0.03$ & $0.58 \pm 0.02$ \\
& & & & \\
Mineral composition & & & & \\
Calcium & $102.33 \pm 2.40$ & $99.33 \pm 1.33$ & $101.33 \pm 7.42$ & $94.33 \pm 5.56$ \\
Magnesium & $10.23 \pm 1.09$ & $10.20 \pm 1.10$ & $10.73 \pm 0.79$ & $9.40 \pm 1.03$ \\
Phosphorus & $57.67 \pm 3.76$ & $61.67 \pm 6.64$ & $62.00 \pm 8.51$ & $54.67 \pm 6.12$ \\
Iron & $0.02 \pm 0.00^{\mathrm{ab}}$ & $0.02 \pm 0.00^{\mathrm{b}}$ & $0.03 \pm 0.01^{\mathrm{ab}}$ & $0.05 \pm 0.01^{\mathrm{a}}$ \\
Copper & $0.03 \pm 0.00$ & $0.03 \pm 0.00$ & $0.03 \pm 0.01$ & $0.04 \pm 0.01$ \\
Zinc & $0.31 \pm 0.06$ & $0.46 \pm 0.11$ & $0.35 \pm 0.05$ & $0.27 \pm 0.07$ \\
\hline ab: Means on the same row by factor with different superscripts differ significantly $(\mathrm{P}<0.05) .0 \mathrm{MC}, 0 \%$ Mineral (control); \\
2LP, 2\% Local Potash; 2ML, 2\% Mineral Lick; 2RMP, $2 \%$ Ruminant Mineral Premix. &
\end{tabular}

Many of the minerals, particularly $\mathrm{Ca}, \mathrm{P}$ and $\mathrm{Na}$ have been reported (Ghazanfar et al., 2011) as essential for small ruminants to attain optimum productivity. On the contrary, the levels of $\mathrm{Ca}, \mathrm{Na}, \mathrm{K}$ and $\mathrm{Zn}$ reported for cassava peels (Oboh, 2006) were much lower relative to the nutritional needs of ruminants. In a performance study with goats, Faftine and Zanetti (2010) observed an increased consumption of maize stover with multinutrient blocks. The ash content (8 to 10) of the diets fell within the range reported by Okpara et al. (2014) and Abdu et al. (2012) 
and above the ash contents of $5 \%$ reported by Okafor et al. (2012) and Adamu et al. (2015), respectively. The ADF and Neutral Detergent Fibre (NDF) contents of the diets used in this study were moderate when compared with low quality roughages which ruminants effectively degraded (Okoli et al., 2003). Meissner et al. (1991) reported that browse spp with NDF above 55 to $60 \%$ would reduce the intake of such fodder by ruminants. This is similar to the result obtained in this study as concentrate with the lowest NDF (2PLP) was well consumed. This observation was supported by other report (Fajemisin et al., 2012) in which low dietary fibre fractions and adequate protein content in livestock diets, enhanced nutrient intake and digestibility. High dietary levels of fibre have also been acknowledged to be inversely related to feed digestibility and nutrient availability (McDonald et al., 1995).

The high Ether Extract (EE) contents (9 and 12) of the diets observed in this study could be attributed to the relative content of oil in Palm kernel cake contained in the diets (Kalio et al., 2014). The EE content in this experiment was above the range of fat 2 and $13 \%$ reported elsewhere (Lamidi and Ogunkunle, 2015 and Amata and Lebari, 2011) for chemical composition, mineral profile and phytochemical properties of common feed resources used for small ruminant animal production in South-West, Nigeria.

The milk yield values obtained in this experiment were higher when compared to those observed for WAD goats in another report (Bawala et al., 2006). Akinsoyinu et al. (1977) observed low milk yield in WAD goats while Adewumi and Olorunisomo (2009) found that milk yield was related to body size in WAD sheep. Makun et al. (2013) observed significant effect of breed and protein supplementation on milk yield of indigenous goats in Nigeria. Thus, the high milk yield of the WAD goats in this study could be attributed to feed intake and different mineral sources in the experimental diets.

The $\mathrm{Ca}$ and $\mathrm{P}$ content of the colostrum observed in this study were much higher than the values in mature milk. Similar to the report of Ogunwole (2016) for cow's and ewe's colostrum. Ojoawo and Akinsoyinu, (2014) revealed that colostrums of WAD does contained higher percentages of all minerals (except calcium) than milk secreted later. The values recorded for lactose in the colostrum of WAD goats in this experiment fall in the range of lactose concentration recorded by Ahamefule et al. (2003) in early, mid and late lactation stages in West African Dwarf goat.

The main mineral compounds of milk are calcium and phosphorus, which are substantial for bone growth and proper development of new born (Al-Wabel, 2008). The mean level of $\mathrm{Ca}$ in goat milk in the present study was lower to the mean level reported by Pinto et al. (1992). The variation of $\mathrm{Ca}$ concentration in milk may be related to species, absorption and availability of $\mathrm{Ca}$ to the animal. In addition, the level of $P$ in goat milk in the present study was similar to the level reported by Idris (2015) but it was lower than the values in West African Dwarf goat reported by Akinsoyinu and Akinyele (1979). Jean and Randy (2002) reported the following values for magnesium in milk cow $(18.66 \mathrm{mg} / 100 \mathrm{~g})$, human $(4.34 \mathrm{mg} / 100 \mathrm{~g})$, sheep $(-25.94$ $\mathrm{mg} / 100 \mathrm{~g})$ and goat $(-20 \mathrm{mg} / 100 \mathrm{~g})$. However, Mba (1975) observed that milk from WAD goats contained higher levels of magnesium. Iron concentration in milk is naturally low and influenced by the presence of lactoferrin and xanthine oxidase transferase (Al-Wabel, 2008). Iron, zinc, and copper in ruminant milk are related mainly to the casein fraction, whereas in human milk they are connected to soluble proteins (Raynal-Ljutovac et al., 2008). Iron has the lowest concentration of all the minerals observed. Similar observation was given by Barłowska et al. (2011) who reported that goat milk was characterized by low concentration of iron, zinc and copper. The explanation for this is that goat milk contains a higher share of nucleotides which contribute to heightened absorption in the intestine (Raynal-Ljutovac et al., 2008).

Mineral nutrients from different sources on milk proximate of WAD goats in this study had significant effect only on total solid, an observation that is similar to the reports of Ogunbosoye and Babayemi, (2010) on milk composition. The values of total solids in this study were lower than the values obtained by Alawa and Oji (2008). Beyene and Seifu (2005) observed an increase in total solid that reached a maximum at mid-lactation and then decreased. Lactose and total ash composition values were at variance with other results (Ogunbosoye and Babayemi, 2010). It has been documented (Ahamefule et al., 2012) that the concentration of lactose in milk cannot be easily altered by nutrition. Sources of mineral nutrients did not have a significant effect on protein content of milk in this study which could be due to steady nutrition and management practices to which the animals were subjected throughout the period of the study. This might have suppressed the effect of different mineral nutrients on protein content of the goat milk. This agrees with other findings (Egbowon, 2004) which reported higher and lower proportion of milk components in well-fed and under-fed goats respectively.

\section{Conclusion}

In conclusion, for high milk yield, diets containing $2 \mathrm{ML}$ could be fed to WAD Does.

\section{CONFLICT OF INTEREST}

The authors declare that they have no conflict of interest.

\section{REFERENCES}

Abdu, S. B., Hassan, M. R., Jokthan, G. E., Adamu, H. Y., 
Yashim, S. M., \& Yusuf, K. (2012). Effect of varied inclusion levels of Gmelina (Gmelina arborea) leaf meal on intake, digestibility and nitrogen in Red Sokoto bucks fed on sorghum glum based complete diets. Advance Agriculture Science Eng. Research, 2, 79-84.

Adamu, H. Y., Lamidi, O. S., Ehoche, O. W., Abdu, S. B., Hassan, M. R., \& Yashim, S. M. (2015). Growth performance of Yankasa sheep fed varying proportions of white beech (Gmelina arborea) leaves. http://www.academia.edu/5831079.

Adebambo, A. O., Samuel, O. A., \& Onakade, A. D. (1994). Causes of variation in reproductive performance of West African Dwarf goat. Nigerian Journal of Animal Production, 21, 29-36.

Adewumi, O. O., \& Olorunisomo, O. A. (2009). Milk yield and milk composition of West African Dwarf Yankasa and crossbred sheep in Southwest of Nigeria. Livestock Research for Rural Development, 21(3).

Ahamefule, F. O., Ibeawuchi, J. A., \& Ejiofor, C. A. (2003). A comparative study of the constituents of cattle, sheep and goat milk in a hot humid environment. Discovery and Innovation, 15(1), 64-69.

Ahamefule, F. O., Odilinye, O., \& Nwachukwu, E. N. (2012). Milk Yield and Composition of Red Sokoto and Wea Dwarf Does Raised Intensively in a Hot Humid Environment. Iranian Journal of Applied Animal Science 2(2), 143-149.

Aina, A. B. J., \& Akinsoyinu, A. O. (1996). Effect of dietary copper supplementation on serum copper level and performance of female West African Dwarf (Fouta djallon) goats. Nigerian Journal of Animal Science 23(1), 61-65.

Aina, A. B. J. (2012). Goat (Capra Hircus): A Misunderstood Animal. FUNAAB Inaugural Lecture, Series No. 35.

Akinsoyinu, A. O., Mba, A. U., \& Olubajo, F. O. (1977). Studies on milk yield and composition of the West African dwarf goat in Nigeria. Journal of Dairy Research. 44, 57-62.

Akinsoyinu, A. O., \& Akinyele, I. O. (1979). Major elements in milk of the West African dwarf goats as affected by stage of lactation. Journal of Dairy Research, 46(3), 427-431.

Alawa, J. P., \& Oji, U. I. (2008). Effect of pendulous udder enlargement on yield and proximate composition of milk from red sokoto goats. Journal of Animal Vetenary Advance, 7, 870872.

Al-Wabel, N. A. (2008). Mineral contents of milk of cattle, camels, goats and sheep in the central region of Saudi Arabia. Asian Journal Biochemistry, 3, 373-375.

Amata, I. A., \& Lebari, T. (2011). Comparative evaluation of the nutrient profile of four selected browse plants in the tropics, recommended for use as non-conventional livestock feeding materials. African Journal of Biotechnology, 10, 14230-14233.

Arigbede, O. M. (2007). Performance of West African Dwarf (Wad) Goats Fed Panicum Maximum Basal Diet with Different Sources of Protein Supplements. ASSET: An International Journal (Series A), 7(1), 79-85.

Asaolu, V. O., Akinlade, J. A., Aderinola, O. A., Okewoye, A. T., \& Alalade, J. A. (2012). Performance of Grazing West African Dwarf Goats on Moringa Multinutrient Block Supplementation. Asian Journal of Animal Sciences, 6, 263-277.

Barłowska, J., Szwajkowska, M., Litwi'Nczuk, Z., \& Kr'ol, J. (2011). Nutritional Value and Technological Suitability of Milk from Various Animal Species Used for Dairy Production. Comprehensive Reviews in Food Science and Food Safety, 10, 291-302.

Bawala, T. O., Isah, O. A., \& Akinsoyinu, A. O. (2006). Studies on milk mineral composition of lactating West African Dwarf goats. Medwell Journal of Animal and Veterrinary Advances. 6(12), 1458- 1463.

Belewu, M. A., \& Aiyegbusi, O. F. (2002). Comparison of the mineral content and apparent biological value of milk from human, cow and goat. Journal of Food Technology in Africa, 7(1), 9-11.

Beyene, F., \& Seifu, E. (2000). Variations in quality and fermentation properties of milk from local goats. In The opportunities and challenges of enhancing goat production in East Africa: Proceeding of a conference held at Awassa, Debub University (pp. 201-211).

Blench, R. (1999). Traditional livestock breeds: geographical distribution and dynamics in relation to the ecology of West Africa (pp. 44-50). London: Overseas Development Institute. Available at https://www.odi.org/resources/docs/2766.pdf.

Dubeuf, J. P., \& Boyazoglu, J. (2009). An International panorama of goats selection breeds. Livestock Science, 120, 225-231.

Egbowon, B. F. (2004). Comparative Evaluation of Milk Secretion Rate and Milk Composition in West African Dwarf and Red Sokoto goats. M.Sc. Thesis Department of Animal Breeding and Genetics, University of Agriculture, Abeokuta, Nigeria. Pp. 35-47.

Faftine, O. L. J., \& Zanetti, A. M. (2010). Effect of multinutrient block on feed digestibility and performance of goats fed maize stover during the dry season in south of Mozambique. Livestock Research for Rural Development. Volume 22, Article 162. Retrieved January 18, 2018, from http://www.Irrd.org//rrd22/9/faft22162.htm.

Fajemisin, A. N., Chineke, C. M., Fadiyimu, A. A., Fajemisin, A. J., \& Alokan, J. A. (2012). Dietary effects of ensiled corncobs treated with or without water, lye and urea on performance characteristics of West African Dwarf sheep. Proceedings of 17th Annual Conference, Animal Science Association of Nigeria (ASAN) held at International Conference Centre, Opposite Radio House, Area 8, Abuja, (FCT), Nigeria, 9th 13th September, 2012. Pp. 575-578.

Fasae, O. A., Alokan, J. A., \& Onibi, G. E. (2005). Feed intakes of Yankassa sheep fed varying levels of Leucaena leucocephala leaf residues. Nigerian Journal of Animal Production, 32(1), 88-93.

Ghazanfar, S., Latif, A., Mirza, I. H., \& Nadeem, M. A. (2011). Macro-minerals concentrations of major fodder tree leaves and shrubs of District Chakwal, Pakistan. Pakistan Journal of Nutrition, 10, 480-484.

Gupta, S., Gupta, H. K., \& Soni, J. (2005). Effect of vitamin E and selenium supplementation on concentrations of plasma cortisol and erythrocyte lipid peroxides and the incidence of retained foetal membranes in crossbed dairy cattle. Theriogenology, 64, 1273-1286.

Hurley, W. L. (2002). Lactation Biology. University of Illinois http://animsciagrenvimcgill.ca/courses/460/topics/2/text. pdf

Idris, M. G. (2015). Milk Composition of Camels and Goats Grazing in Butana Area. http://hdl.handle.net/123456789/7975.

Jean, L., \& Randy, W. (2002). Milk, Doing Your Body Good? Journal of Young Investigators. 6(3). Available at http://legacy.jyi.org/volumes/volume6/issue3/features/lee_and wei.html.

Kalio, G. A., Ayuk, A. A., \& Agwunobi, L. N. (2014). Performance of West African Dwarf (WAD) Goats Fed N-treated Source and Forage Supplemented Cassava Peels in Humid Cross River State, Nigeria. American Journal of Experimental Agriculture, 
4(6), 629-638.

Lamidi, A. A., \& Ogunkunle, T. (2015). Chemical composition, mineral profile and phytochemical properties of common feed resources used for small ruminant animal production in southwest, Nigeria. International Journal of Science and Nature, 6, 92-96.

Logan, F. F., Rice, D. A., Smyth, J. A. \& Ellis, W. A. (1990). Weak calf syndrome and parenteral selenium supplementation. Vetenary Record, 126, 163-164.

Makun, H., Otaru, S. M., \& Dung, D. (2013). Effect of management practices on milk yield and liveweight changes of indigenous breeds of goats supplemented with groundnut haulms and concentrate in sub humid zone of Nigeria. Sokoto Journal of Veterinary Sciences, 11(1), 45-50.

Marshall, R. T. (1993). Standard methods for examination of dairy product. 16th ed. American Public Health Association, Washington DC., USA.

Mba, A. U. (1975). Studies on the milk of West African Dwarf, Red Sokoto and Saanen goats at different stages of lactation. Journal of Dairy Research 42, 217-226.

Mcdonald, P., Edward, R. A., \& Greenhalgh, J. F. D. (1995). Animal Nutrition. 5th edition. Longman, London.

Mee, J. F. (2004). The role of micronutrients in bovine periparturient problems. Cattle Practice, 12, 95-108.

Meissner, H. H., Viljoen, M. D., \& Van Nierkeki, W. A. (1991). Intake and digestibility by sheep of Anthephora, Panicum, Rhode and Smuts finger grass pastures. Proceeding of the 5th International Rangeland Congress, September 1991. Montipellier, France. Pp. 648-649.

Midau, A., Kibon, A., Moruppa, S. M., \& Augustine, C. (2010). Influence of season on milk yield and milk composition of red sokoto goats in mubi area of Adamawa State, Nigeria. Intanational Journal of Dairy Science, 5: 135-141.

Min, B. R., Hart, S. P., Shalu, T., \& Satter, L. D. (2005). The Effect of Diets on Milk Production and Composition, and on Lactation Curves in Pastured Dairy Goats. Journal of Dairy Science, 88, 2604-2615.

Oboh, G. (2006). Nutrient enrichment of cassava peels using a mixed culture of Saccharomyces cerevisae and Lactobacillus sp. solid media fermentation techniques. Electron. Journal of Biotechnology, 9, 46-49.

Ogebe, P. O., Ogunmodede, B. K., \& McDowell, L. R. (1995). Performance of browsing west african dwarf kids fed graded levels of sodium supplements. Livestock Research for Rural Development, 7,1

Ogunbosoye, D. O., \& Babayemi, O. J. (2010). The Effect of forage based diets on milk Composition, Lactation stages and Growth Rate kids from West African dwarf (WAD) goat in South West Nigeria. In Natural Resource Management and Rural Development. ETH Zurich, Conference on International Research on Food Security September. Pp. 14-16.
Ogunwole, O. A. (2016). Manganese, Zinc and Chloride Content of Milk of West African Dwarf Goats as Influenced by stage of Lactation. International Journal of Biochemistry Research \& Review, 12(3), 1-6.

Ojoawo, O. T., \& Akinsoyinu, A. O. (2014). Sodium, Potassium and Magnesium in milk of West African Dwarf Does as influenced by Lactation Stages. Journal of Agriculture and Environmental Sciences, 3(2), 333-343.

Okafor, E. C., Lakpini, C. A. M., \& Fayomi, A. (2012). Dried Gmelina (Gmelina arborea Roxb) leaves as replacement forage to groundnut haulms in the diet of fattening Red Sokoto bucks. International Journal of Agricultural Bioscience, 1, 5-10.

Okoli, I. C., Anunobi, M. O., Obua, B. E., \& Enemuo, V. (2003). Studies on selected browses of South Eastern Nigeria with particular reference to their proximate and some endogenous anti-nutritional constituents. Livestock research for rural development, 15(9), 3-7.

Okpara, O., Akporhuarho, P. O., \& Okagbare, G. O. (2014). Determination of browse intake and nutrient digestibility of grazing West African Dwarf (WAD) goats fed varying levels of Gmelina arborea leaves as supplements in delta state Nigeria. International Journal of Animal Veterinary Advance, 6, 52-57.

Pauzenga, U. (1985). Feeding parent stock. Zootecnica International, 17, 22-24.

Pinto, C. M., Brito, C. C., Fraser, L. B., Molina, C. L. H., \& Gomez, C. E. (1992). Chemical composition of cross breed Saanen goats milk. Journal of Terra Arida, 11, 138-144.

Ranjahan, S. K. (2004). Animal Nutrition in the Tropics. Published by Vikas Publishing House, PVT, LMD. 5th Edition, Pp. 36-37.

Raynal-Ljutovac, K., Lagriffoul, G., Paccard, P., Guillet, I., \& Chilliard, Y. (2008). Composition of goat and sheep milk products. Small Ruminant Research, 79(1), 57-72.

SAS (2000). SAS/STAT Guide for personal computers. Version 6 S.A.S. Inst. Inc. Cary. New York, USA.

Williams, T. J., Osinowo, O. A., Smith, O. F., James, I. J., Ikeobi, C. O. N., Onagbesan, O. M., Shittu, O. O. and Solola, F. T. (2012). Effects of milking frequency on milk yield, dry matter intake and efficiency of feed utilization in wad goats. Archivos de zootecnia. 61(235), 457-465.

Yousuf, M. B., Belewu, M. A., GBADAMOSIP, A., \& Ogudun, N. I. (2007). Replacing Cotton Seed Cake with Cassava Leaf Meal. Bulgarian Journal of Agricultural Science, 13, 231-236. 